PATRIMÔNIO

\section{Ocupe Estelita: movimento social e cultural defende marco histórico de Recife}

Uma área de cerca de 101,7 mil metros quadrados, com um pátio ferroviário e uma série de armazéns de açúcar abandonados pelo poder público. Quem olha de fora vê apenas isso, mas quem conhece a história do Cais José Estelita sabe que o local faz parte da história de Recife, sendo um dos cartôes postais e um dos poucos espaços públicos que restam na capital pernambucana. E é por isso que um grupo está lutando para evitar que as construções sejam demolidas por um consórcio de grandes construtoras para construção de prédios comerciais e residenciais.

O movimento Ocupe Estelita é formado por advogados, arquitetos, sociólogos, artistas, professores, engenheiros, estudantes, médicos, administradores, publicitários, jornalistas, designers e antropólogos, entre outros, que, desde 2012, luta contra a destruição desse marco da cidade. Mas o objetivo do grupo vai além: "A luta do movimento Ocupe Estelita é para que a cidadania ocupe o cais por meio da observância da legislação vigente; da inclusão popular no desenho das oportunidades para a área do centro-sul da capital pernambucana; do respeito ao meio ambiente e do investimento imobiliário responsável", explica o grupo em seu website.

A luta começou em 2008, quando o consórcio imobiliário Novo Recife, formado pelas construtoras Moura Dubeux, Queiroz Galvão, Ara Empreendimentos e GL Empreendimentos, comprou em leilão a área da antiga Rede Ferroviária Federal (RFFSA) por $\mathrm{R} \$ 55$ milhões. O projeto visava construir mais de 12 torres residenciais e comerciais de alto padrão, com até 40 andares (apartamentos de R \$400 mil e R \$1 milhão), além de estacionamentos para cerca de cinco mil veículos. O plano causou indignação em grande parte da população, que começou a se mobilizar para acompanhar as reuniōes do Conselho de Desenvolvimento Urbano (CDU) da prefeitura de Recife. O que começou como uma reivindicação por mais diálogo e participação popular levou à criação do grupo Direitos Urbanos (DU), que hoje representa a maioria dos integrantes do movimento Ocupe Estelita.

PRESSÃO POPULAR Em 23 de maio de 2012 ocorreu a primeira audiência pública sobre o projeto Novo Recife, na qual parte da população teve acesso ao projeto e apontou vários problemas que ele poderia causar no cais e na cidade como um todo - entre eles a perda de parte da história e da identidade do Recife. "Foi impressionante porque a sociedade civil participou em peso. A câmara ficou tomada por pessoas que queriam acompanhar o debate", conta a advogada Liana Cirne Lins, professora do Departamento de Direito Público Geral e Processual da Universidade Federal de Pernambuco (UFPE) e integrante do movimento. Apesar de toda a mobilização social, em 2014 o Consórcio Novo Recife deu início à demolição do cais. A operação, que começou por volta da meia noite, chamou a atenção de um dos ativistas, que enviou imagens $\mathrm{da}$ destruição por celular para outros ativistas, que espalharam a notícia pelas redes sociais. As pessoas reunidas decidiram passar a noite no local vigiando para que as máquinas não voltassem a derrubar os armazéns. $\mathrm{O}$ acampamento, que era para ser por uma noite, acabou durando 58 dias, atraindo cada vez mais pessoas.

A pressão popular foi tanta que a prefeitura teve que abrir o diálogo com os ativistas e está concordando em renegociar o projeto Novo Recife. Já foram realizadas quatro rodadas de debates sobre o assunto e várias mudanças foram propostas, mas ainda nenhuma ação concreta. Durante uma das discussões, o prefeito Geraldo Júlio (PSB) afirmou: "nós estamos aqui abrindo uma janela que será importante se todo mundo quiser usá-la. Esse é um processo rico, importante, que nos possibilita a negociação. E esse deve ser o papel 


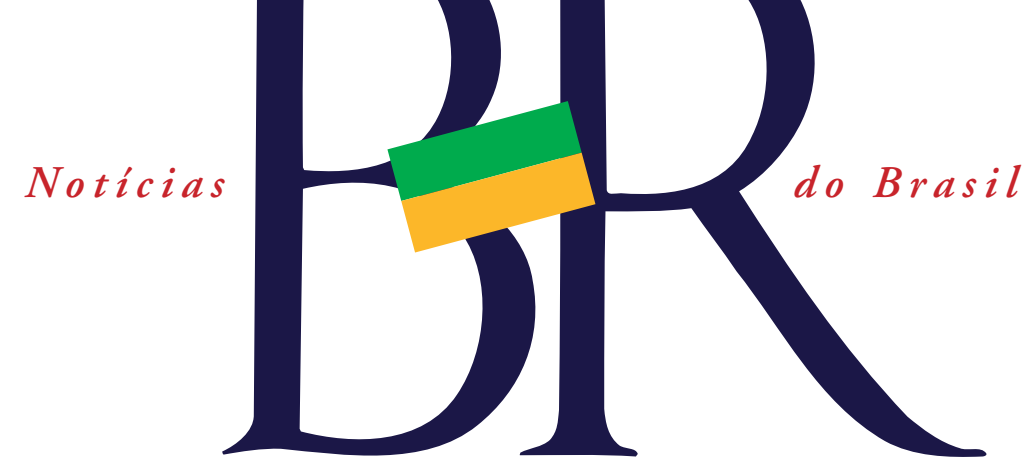

da prefeitura. Hoje, não debatemos questôes de mérito, mas de abertura de diálogo entre as partes”.

IRREGULARIDADES O movimento Ocupe Estelita e o grupo Direitos Urbanos apontam que há uma série de irregularidades ou, ao menos, pontos não muito claros, no projeto Novo Recife. O primeiro deles é que o leilão da área, uma propriedade da Federação, não poderia ter sido feito sem consulta a outros órgãos públicos que eventualmente tivessem interesse nela. No entanto, o leilão ocorreu mesmo com a manifestação de interesse do Instituto do Patrimônio Histórico e Artístico Nacional (Iphan), de Pernambuco, pela área. Além disso, apenas uma empresa - o Consórcio Novo Recife - participou e, com isso, pagou o valor mínimo estipulado.

Outro problema é que procedimentos básicos para projetosimobiliários dessa magnitude não foram cumpridos como estudos de impacto de vizinhança e de impacto ambiental. $\mathrm{O}$ projeto não foi submetido à análise do Iphan, do Departamento Nacional de Infraestrutura de Transportes (DNIT) e da Agência Nacional de Transportes Terrestres (ANTT). Tudo isso gerou três ações populares e duas do Ministério Público Fede-

ral e Estadual. "O que acontece é que o poder público e o econômico decidem de forma isolada sobre os modos de ocupação dos espaços da cidade, sem ouvir a opinião do povo, que vai ter que arcar com as más escolhas desses poderes", aponta Lins.

MOVIMENTO CULTURAL O Ocupe Estelita não é apenas um movimento social, é também cultural. O grupo tem chamado a atenção e recebido apoio de diversos artistas, como Ney Matogrosso, Zélia Duncan, Kléber Mendonça, Nação Zumbi e Xico Sá. Mas não é só isso: com o apoio estrutural do Som na Rural, projeto de música itinerante da capital pernambucana, o movimento conseguiu levar nomes da cena musical de Recife, como Karina Buhr, Otto e Lirinha, para fazer shows de graça no cais que atraíram mais de 10 mil pessoas. "Além dos shows, tivemos oficinas de haikai, poesia, malabares, confecção de livros. Oferecemos 'aulóes' ministrados por professores universitários; debates; apresentações de maracatu, capoeira, blocos de carnaval", conta Lins.

A CIDADE É NOSSA O grito de guerra do movimento Ocupe Estelita é "A cidade é nossa. Ocupe-a”. Isso porque o grupo não quer apenas impedir a destruição do cais, mas também mais participação pública nas decisões da cidade e aproveitamento máximo. "Nosso discurso do direito à cidade é do direito de fruir, de aproveitar tudo o que ela tem para oferecer, de ser feliz nela. A cidade é para isso: para ocuparmos seus espaços públicos dando-lhes uma destinação social, cultural e popular", defende Lins.

A atividade do grupo acabou inspirando mobilizações em outras áreas da cidade-como o projeto, proposto ecancelado pelogoverno, de construir quatro viadutos no coração da cidade, o projeto Via Mangue e o Shopping RioMar - e até fora dela, como é o caso do cais Mauá, em Porto Alegre (RS). "Entramos para a história com uma mensagem positiva, de que vale a pena lutar, vale a pena interferir nos processos da cidade", finaliza Lins.

Chris Bueno 